\title{
地上ディジタル放送用 OFDM 受信機の受信特性
}

\author{
Performance of OFDM Receiver for Digital Terrestrial Television Broadcasting
}

\author{
正会員 佐 藤 誠 ${ }^{\dagger}$, 正会員 工 藤 雄 也 $^{\dagger+\dagger}$, 関 隆 ${ }^{\dagger+}{ }^{\dagger \dagger}$ \\ 正会員 相沢雅 已 ${ }^{+\dagger}$, 正会員 多賀 昇 ${ }^{\dagger}$, 正会員 石川達也地 \\ Makoto Sato ${ }^{\dagger}$, Katsuya Kudo ${ }^{++}$, Takashi Seki ${ }^{\dagger+}$, \\ Masami Aizawa ${ }^{\dagger+}$, Noboru Taga ${ }^{\dagger}$ and Tatsuya Ishikawa ${ }^{\dagger+}$
}

\begin{abstract}
あらまし 地上ディジタル放送では, マルチパス妨害に加えアナログ放送波からの妨害に対して耐性の高い受 信機が望まれる. 本研究では, これらの妨害に対して受信性能を向上する地上ディジタル放送用 OFDM 受信機 を開発し，その性能を評価した。また，オンエア受信した変調信号を記録再生できる機能を設け, 受信 OFDM 信号を容易に解析することができるようにした。
\end{abstract}

キーワード : 地上デイジタルテレビジョン放送, OFDM, 妨害, 信号解析

\section{1. ま え がき}

我が国の地上ディジタル放送は, 1998 年秋に郵政省の 電気通信技術審議会において「地上デジタルテレビジョン 放送暫定方式」が策定され，1999年 5 月に伝送方式が答 申された ${ }^{1)}$. 我々は, この方式に準拠しUHFテレビジョ ンチャネルの OFDM 受信機を開発した。本稿では受信機 の概要と基本性能および周波数選択性妨害に対する性能改 善について報告する．

また，受信特性の解析を効率的に行うことができるよ う,オンエア受信した変調信号を記録再生できるようにし た。これを用いた解析結果についても述べる.

\section{OFDM 受信機の構成}

\section{1 概 要}

OFDM 受信機の構成図を図 1, 外観を図 2 に示す.

また, 入出力機能を表 1 に示す. OFDM 受信機に入力

1999 年 10 月 29 日 映像情報メディア学会放送方式研究会で発表

2000 年 2 月 23 日受付, 2000 年 4 月 16 日再受付, 2000 年 5 月 8 日採録

†東芝デジタルメディアエンジニアリング株式会社 （テ 235-8522 横浜市磯子区新杉田町 8, TEL 045-770-3311)

† 株式会社東芝 セミコンダクター社 システム LSI 事業部 （テ 235-8522 横浜市磯子区新杉田町 8, TEL 045-770-3311)

†† 株式会社東芝デジタルメディアネットワーク社 深谷映像工場 （テ 366-8510 深谷市幡羅町 1-9-2, TEL 048-574-2480)

$\dagger$ Toshiba Digital Media Engineering Corp. (8, Shinsugita-cho, Isogo-ku, Yokohama 235-8522, Japan)

†† Toshiba Corp. Semiconductor Company, System LSI Division (8, Shinsugita-cho, Isogo-ku, Yokohama 235-8522, Japan)

†† Toshiba Corp. Digital Media Network Company, Fukaya Operations-Visual Products

(1-9-2, Hatara-cho, Fukaya-shi, Saitama 366-8510, Japan)

904 (154)
された RF 信号(UHF チャネル $13 \mathrm{ch}$ から $62 \mathrm{ch}$ のいずれ か 1 波) はチューナ部で選局され, $4.1 \mathrm{MHz}$ の IF 信号が 出力される. RF 信号が $1 / 7 \mathrm{MHz}$ 周波数オフセットされ る場合には，チューナの局部発振周波数を同様にオフセッ トさせ, IF 周波数を変更せずに対応することができる.

IF 信号は A/D 変換され, OFDM 復調処理と誤り訂正 処理の後, MPEG-2 トランスポートストリーム形式準拠 のデータとして出力される. 本受信機ではこれらの機能を $\mathrm{W} 443 \mathrm{~mm} \times \mathrm{H} 132 \mathrm{~mm} \times \mathrm{D} 500 \mathrm{~mm}$ の大きさ(図 2 参照) で実現した。

\section{2 チューナ}

表 2 にチューナの特性を示す。隣接アナログ波妨害を充 分に抑圧するため, $57 \mathrm{MHz}$ IF にて下側隣接音声キャリ ヤ抑圧量 $17 \mathrm{~dB}$, 上側隣接映像キャリヤ抑圧量 $40 \mathrm{~dB}$ の $\mathrm{SAW}$ フィルタを 2 段縦続接続し, さらに下側隣接音声キ ヤリアを $4.1 \mathrm{MHz}$ IF 段で抑圧している。また, OFDM 受信機で重要とされる位相雑音も $64 \mathrm{QAM} て ゙$ 問題ない程 度の特性である。これらを民生用テレビチューナと同様の パッケージに収めた。

\section{3 復調処理}

復調処理は同期(クロック，キャリヤおよびタイミング) 回路, FFT 回路およびパイロット補間・等化回路により 構成される．各階層に応じて差動検波あるいは同期検波を 行い，周波数と時間のデインタリーブ処理を行う.

本装置では, パイロット信号を利用して入力信号および チューナの位相雑音を除去するとともに, 周波数選択性妨 害を受けたキャリヤを平均振幅, 分散などから検出し性能 改善を図っている。

映像情報メディア学会誌 Vol. 54, No. 6, pp. 904〜910（2000） 


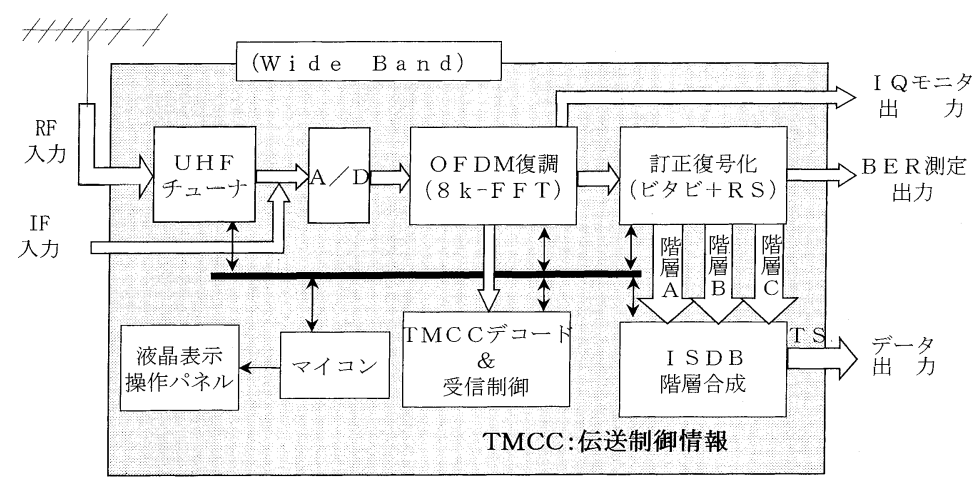

図 1 OFDM 受信機の構成図

Block diagram of OFDM receiver.

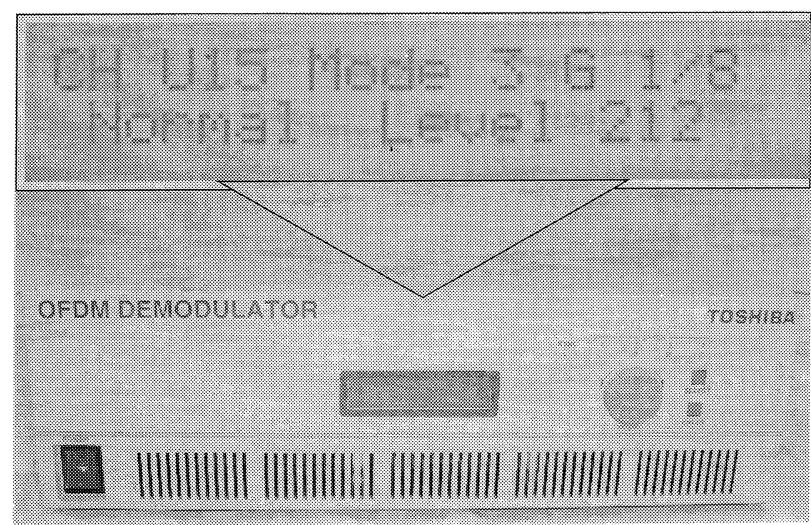

図 2 OFDM 受信機の外観

Photograph of OFDM receiver.

表 1 OFDM 受信機の機能

Specifications of OFDM receiver.

\begin{tabular}{c|l}
\hline \hline & \multicolumn{1}{|c}{ 入出力仕様 } \\
\hline $\mathrm{RF}$ & $\mathrm{UHF}$ テレビチャネルの 1 波 \\
入力 & $\begin{array}{l}13 \mathrm{ch}(470-476 \mathrm{MHz}) \sim 62 \mathrm{ch}(764-770 \mathrm{MHz}) \\
\text { 部分受信階層を含む }\end{array}$ \\
\cline { 2 - 2 } & $+1 / 7 \mathrm{MHz}$ オヤット対応可能 \\
\cline { 2 - 2 } & $-20 \mathrm{dBm} \sim-70 \mathrm{dBm} / 75 \Omega$ \\
\hline \multirow{2}{*}{ 入力 } & $4.1 \mathrm{MHz} \pm 3 \mathrm{MHz}$ \\
\cline { 2 - 2 } & $0 \mathrm{dBm} / 75 \Omega$ \\
\hline \multirow{2}{*}{ 出力 } & $\mathrm{TS}$ 信号 $\times 2(\mathrm{DVB}$ 準拠パラレル $\mathrm{I} / \mathrm{F})$ \\
\cline { 2 - 2 } & LVDS \\
\hline
\end{tabular}

\section{4 誤り訂正処理}

内符号のビタビ復号, バイト・デインタリーブ, エネル ギ一逆拡散の後, 外符号 $(\mathrm{RS})$ が復号される. 周波数選択 性妨害(マルチパス，スプリアス，アナログ同一妨害など) を受けたキャリヤに対しては, 以下の方法で受信性能を改 善した。

（1）平均振幅より小さい $\mathrm{OFDM}$ キャリヤは $C / N$ が 劣化しているのと等価である。誤り率に関して信頼
表 2 チューナの特性

Specifications of RF tuner.

\begin{tabular}{|c|c|}
\hline 入力周波数 & $470 \sim 770 \mathrm{MHz}$ \\
\hline 入力レベル & $-20 \mathrm{dBm} \sim-80 \mathrm{dBm} / 75 \Omega$ typ. \\
\hline 選局ステップ & $1 / 7 \mathrm{MHz}$ \\
\hline 第一中間周波数 & $57 \mathrm{MHz}$ \\
\hline 第二中間周波数 & $4.1 \mathrm{MHz}$ \\
\hline 雑音指数 (NF) & 7 dB typ. \\
\hline $\begin{array}{l}\text { 位相雑音 } \\
1 \mathrm{kHz} \text { offset } \\
10 \mathrm{kHz} \text { offset }\end{array}$ & $\begin{array}{l}-70 \mathrm{dBc} / \mathrm{Hz} \text { typ. } \\
-90 \mathrm{dBc} / \mathrm{Hz} \text { typ. }\end{array}$ \\
\hline 外形寸法 & (W) $116 \mathrm{~mm} \times(\mathrm{D}) 33 \mathrm{~mm} \times(\mathrm{H}) 13 \mathrm{~mm}$ \\
\hline
\end{tabular}

性が低いと見なせるので，軟判定の際に小さい重み づけを行ってビタビ復号する2).

（2）狭帯域妨害を受けると特定 OFDM キャリヤが劣 化する。コンスタレーション基準点からの分散を求 め，それが大きいときにはビタビ復号で消失扱いと する3).

\section{3. 室 内 実 験}

実験に用いたパラメータを表 3 ，系統図を図 3 に示す. 誤り率の測定では外符号 $\operatorname{RS}(204,188)$ はオフとし, ビ夕 ビ復号前後で測定した。ビタビ復号後のビット誤り率では $2 \mathrm{E}-4$ 以下 (RS 訂正後ビット誤り率 $1 \mathrm{E}-11)$ を擬似エラー フリーと見なし基準とした。

基本特性として, AWGN 条件下での IF 入力時と, 入 カレベルを変化させた RF 入力時の誤り率を測定した.ま た，妨害条件としてマルチパスおよびアナログからディジ タルへの干渉条件でも誤り率を測定した。

\subsection{IF および RF 基本特性}

図 4 に IF 折返し(AWGN)でのビタビ復号前の誤り率 測定結果を示す。各変調方式とも測定結果は理論值にほほ 一致しており, キャリヤ数の違いによる差もほとんどなか った。 
表 3 実験に用いた伝送パラメータ

Transmission parameters on laboratory experiment.

\begin{tabular}{l|l}
\hline \hline モード & Mode 2, Mode 3 \\
\hline ガードインタバル長 $G$ & $\begin{array}{l}\text { (有効シンボル期間との比) } \\
1 / 8,1 / 32\end{array}$ \\
\hline 時間インタリーブ長 $I$ & 8,4 \\
\hline キャリア変調方式 & $\begin{array}{l}\text { DQPSK } \\
16 \mathrm{QAM}, 64 \mathrm{QAM}\end{array}$ \\
\hline 内符号(畳込み) $r$ & $1 / 2,2 / 3,3 / 4,5 / 6,7 / 8$ \\
\hline 外符号 & $\mathrm{RS}(204,188)$ \\
\hline 伝送周波数 $(\mathrm{UHF})$ & $\begin{array}{l}\mathrm{ch} 15, \mathrm{ch} 19 \\
+1 / 7 \mathrm{MHz} \text { オフセット }\end{array}$ \\
\hline
\end{tabular}

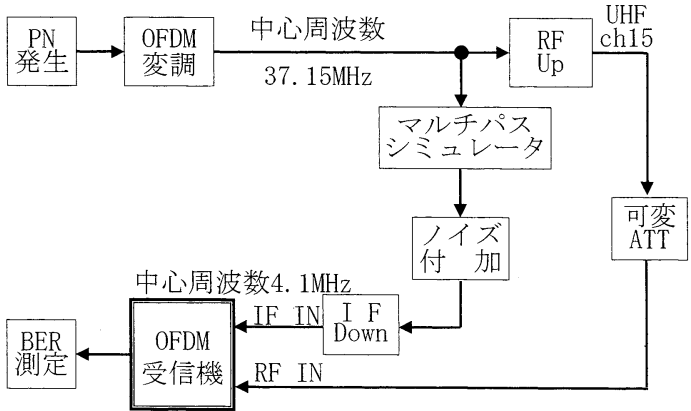

図 3 実験系統図

Block diagram of experimental system.

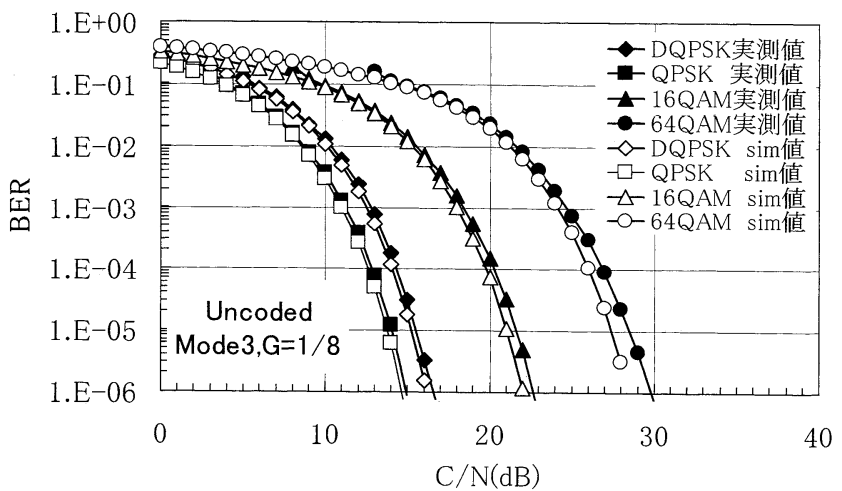

図 4 AWGN 環境下の誤り率特性 BER performance under AWGN condition.

図 5 に, IF 折返し(AWGN)でのビタビ復号後の誤り率 特性を示す。また，誤り率 $2 \mathrm{E}-4$ の基準点での各変調方式 のシミュレーション值と実測值を表 4 に示す。 $64 \mathrm{QAM}$ でも差は $0.3 \mathrm{~dB}$ 以下であり, 固定劣化は非常に小さい.

図 6 に, RF $(15 \mathrm{ch})$ で入力した場合のビタビ復号後の誤 り率特性を変調方式ごとに示す．例えば，64 QAM，符号 化率 $r=7 / 8$ の所要入力レベルは $-76.0 \mathrm{dBm}$ であった.

$\mathrm{NF} 7 \mathrm{~dB}$ のチューナで絶対温度 $T=300 \mathrm{~K}$, 帯域幅 $5.57 \mathrm{MHz}$ の熱雑音は $-106.5+7=-99.5 \mathrm{dBm}$ であり,

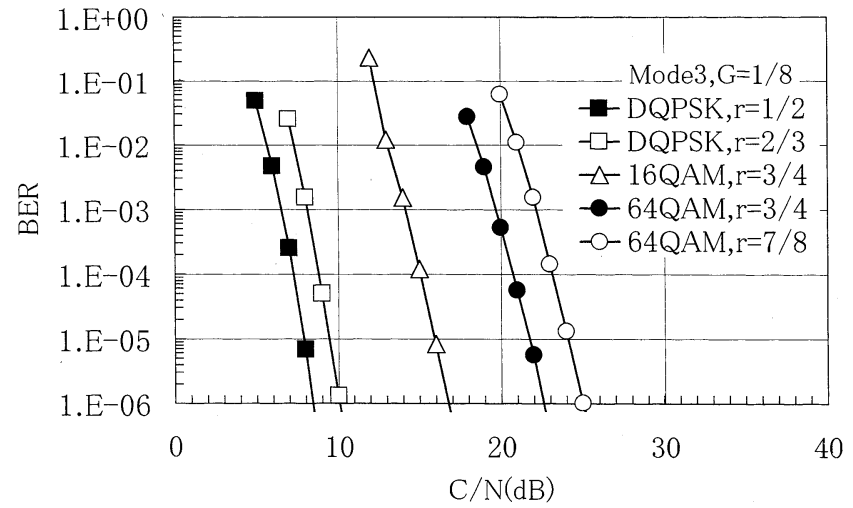

図 5 AWGN 環境下の誤り率特性 (ビタビ復号後) BER performance under AWGN condition (after viterbi).

表 4 所要 $C / N$ と $\mathrm{RF}$ 入力レベル (ビタビ後誤り率 $2 \mathrm{E}-4$ ) Required $C / N$ and input level (ch 15).

\begin{tabular}{|c|c|c|c|c|c|c|}
\hline \multirow{2}{*}{\multicolumn{2}{|c|}{$\begin{array}{c}\text { 変調方式 } \\
\text { 符号化率 }\end{array}$}} & \multicolumn{2}{|c|}{ DQPSK } & \multirow{2}{*}{$\frac{16 \text { QAM }}{3 / 4}$} & \multicolumn{2}{|c|}{64 QAM } \\
\hline & & $1 / 2$ & $2 / 3$ & & $3 / 4$ & $7 / 8$ \\
\hline \multirow{2}{*}{$\begin{array}{c}\text { 所要 } \\
C / N \\
(\mathrm{dBm})\end{array}$} & Sim 値 & 6.5 & 8.2 & 14.8 & 20.5 & 22.7 \\
\hline & 実測値 & 6.6 & 8.3 & 14.9 & 20.7 & 23.0 \\
\hline \multicolumn{2}{|c|}{$\begin{array}{l}\text { 所要 } \mathrm{RF} \text { 入力 } \\
\text { レベル }(\mathrm{dBm})\end{array}$} & -92.7 & -90.8 & -84.2 & -78.8 & -76.0 \\
\hline
\end{tabular}

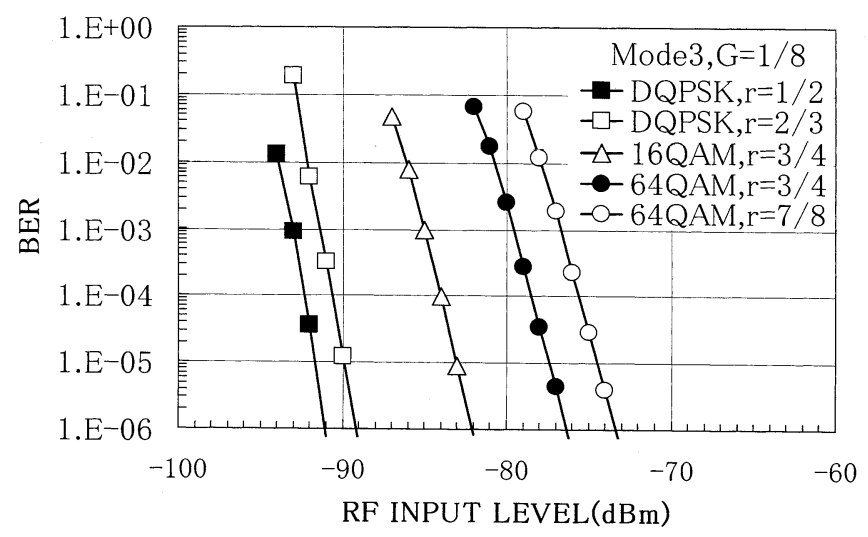

図 6 入力レベル対誤り率特性 BER vs input level performance.

$64 \mathrm{QAM}$, 符号化率 $r=7 / 8$ の所要 $C / N$ は $22.7 \mathrm{~dB}$ であ るから, 所要 $\mathrm{RF}$ 入カレベルは $-76.8 \mathrm{dBm}$ と計算でき る. 表 4 には各変調形式の所要 RF 入力レベルを示してい るが, 実測值と $1 \mathrm{~dB}$ 以内の差である。

\section{2 マルチパス特性}

マルチパス特性の測定は, 遅延波の遅延時間をガードイ ンタバルの $1 / 2(31.5 \mu \mathrm{S})$ に設定し， AWGN 環境下におい てビタビ復号後の誤り率が $2 \mathrm{E}-4$ を満足する $D / U$ を求め た。 
平均振幅による重み付け訂正を用いない場合を図 $7 に$, 用いた場合を図 8 に示す。 64 QAM，符号化率 $r=7 / 8$ の $D / U=4 \mathrm{~dB}$ では約 $1 \mathrm{~dB}$ の改善であるが, $16 \mathrm{QAM}, r=$ $3 / 4$ の $D / U=1 \mathrm{~dB}$ では約 $6.5 \mathrm{~dB}$ の改善, DQPSK, $r=$ $2 / 3$ の $D / U=0 \mathrm{~dB}$ では約 $7 \mathrm{~dB}$, DQPSK, $r=1 / 2$ の $D / U=0 \mathrm{~dB}$ では約 $5 \mathrm{~dB}$ の改善と, 符号化率 $r$ が小さく $D / U$ が小さいときに大きな改善効果を確認した。な押, 図に示されたように，64QAM，符号化率 $r=7 / 8$ では $C / N$ が充分大きくても $D / U=0 \mathrm{~dB}$ でエラーフリーにはな らなかった。このような伝送パラメー夕を単一周波数ネッ トワークで用いると，強電界地域であっても受信場所率が 小さくなると考元られる。

\section{3 アナログからディジタルへの干渉}

図 9 亿室内実験の評価系統図を示す.アナログ波の妨害 はEIA カラーバー, 音声 $1 \mathrm{kHz}$ 変調とし, OFDM の平 均電力を $D, \operatorname{NTSC}$ の同期尖頭值電力を $U$ として, 混合 '器前段に設置したアッテネータ(ATT)にて $D / U$ を設定し た。なお， OFDM 信号の RF 周波数は $+1 / 7 \mathrm{MHz}$ 芯けオ フセットさせている.

アナログ同一チャネル妨害では，テレビ信号成分が映像 キャリヤと音声キャリヤに集中しているため，その近辺の

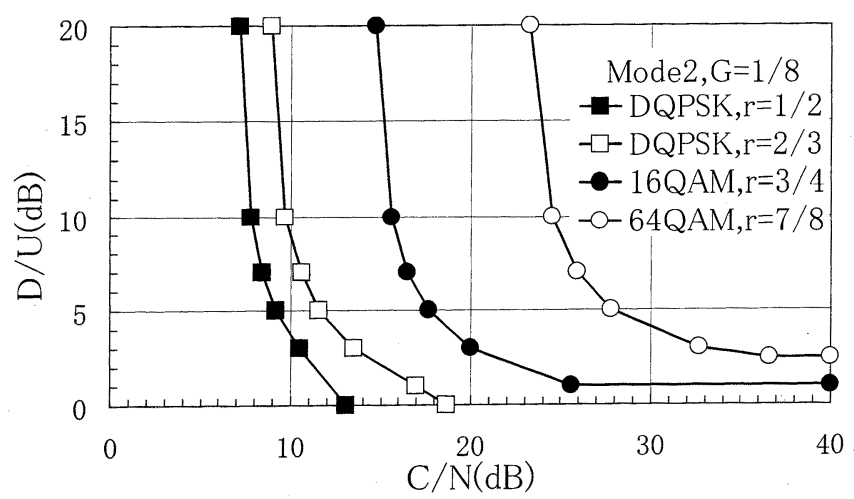

図 7 マルチパス環境下の $C / N$ 対 $D / U$ 特性

$C / N$ vs $D / U$ performance under multipath channel condition.

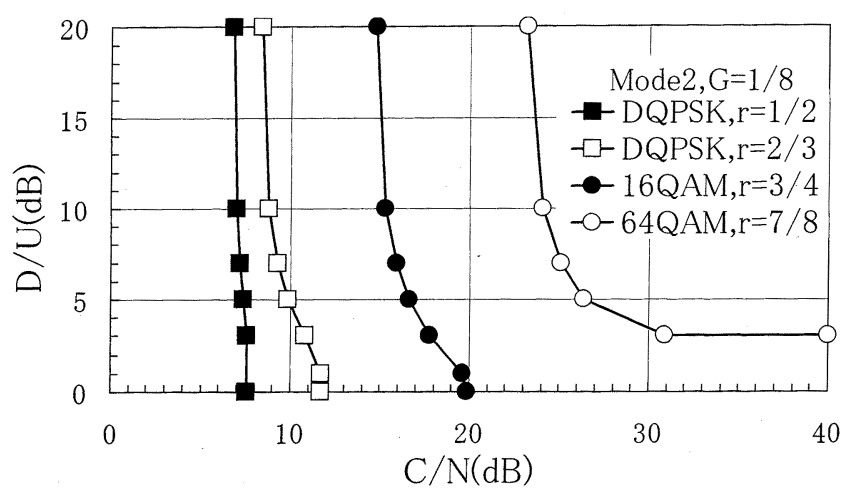

図 8 マルチパス環境下の $C / N$ 対 $D / U$ 特性（改善後） $C / N$ vs $D / U$ performance under multipath channel condition (with reliability weighting).
OFDM キャリヤが集中的に妨害の影響を受ける4)。そこ で, OFDMのキャリヤごとにコンスタレーションの分散 を検出し妨害を受けたキャリヤを判定して消失誤り訂正を 行った。

この機能を用いない場合を図 10 に，用いた場合を図 11 に示す. 改善効果はビタビ復号後の誤り率 2 E-4において $64 \mathrm{QAM}$ ，符号化率 $r=1 / 2,2 / 3,3 / 4,5 / 6,7 / 8$ で，それぞ れ $3 \mathrm{~dB}, 5.4 \mathrm{~dB}, 7.1 \mathrm{~dB}, 10.8 \mathrm{~dB}, 12.7 \mathrm{~dB}$ であり, 符 号化率 $r=$ が大きいほど改善効果が大きかった.

隣接チャネル妨害評価は, アナログテレビ信号の帯域外

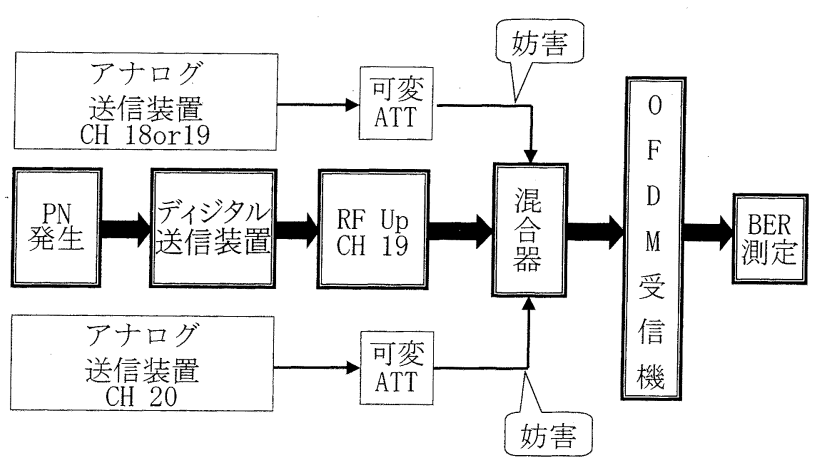

図 9 NTSC テレビ妨害の系統図

Block diagram for analog interference of NTSC TV.

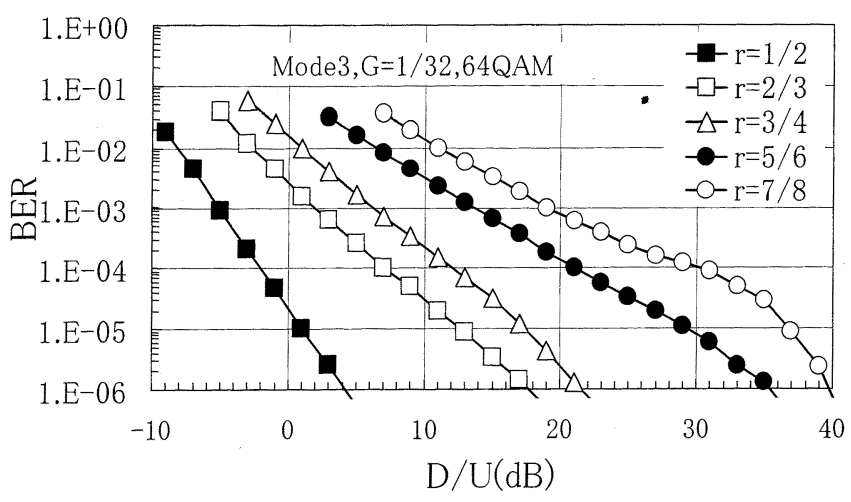

図 10 同一チャネル干涉特性 Co-channel interference.

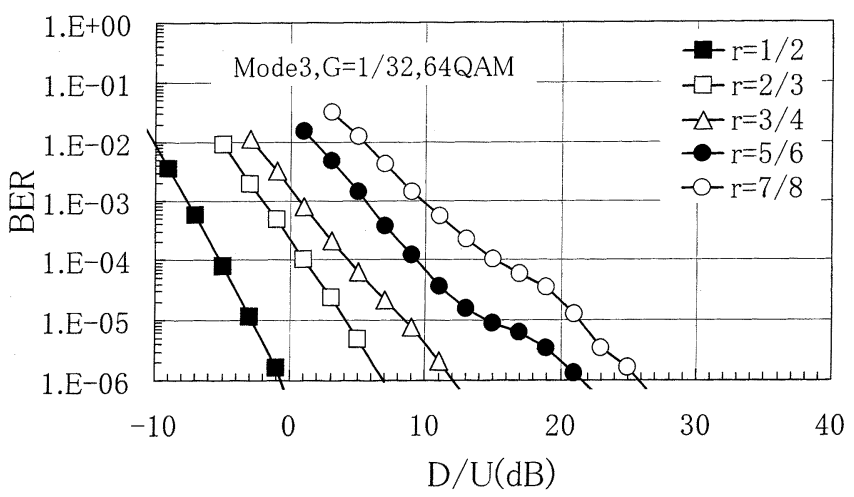

図 11 同一チャネル干渉特性（消失訂正後） Co-channel interference (with erasure decoding). 
スプリアスがない条件 $(-75 \mathrm{dBc}$ 以下) で行った。図 12 に 下側隣接妨害時の実験結果を示す。また，図 13 に上側隣 接妨害, 図 14 に両側隣接妨害時の実験結果を示す. 64 QAM 変調において, RF の入力レベルに対してビタビ復 号後の誤り率が $2 \mathrm{E}-4$ となる妨害波レベル $(U / D)$ を示し てある。

\section{（1）下側隣接妨害}

所要 $D / U$ は RF 入力レベルが $-70 \sim-40 \mathrm{dBm}$ でほぼ 一定であるが， $-40 \mathrm{dBm}$ 以上の入力レベルでは許容

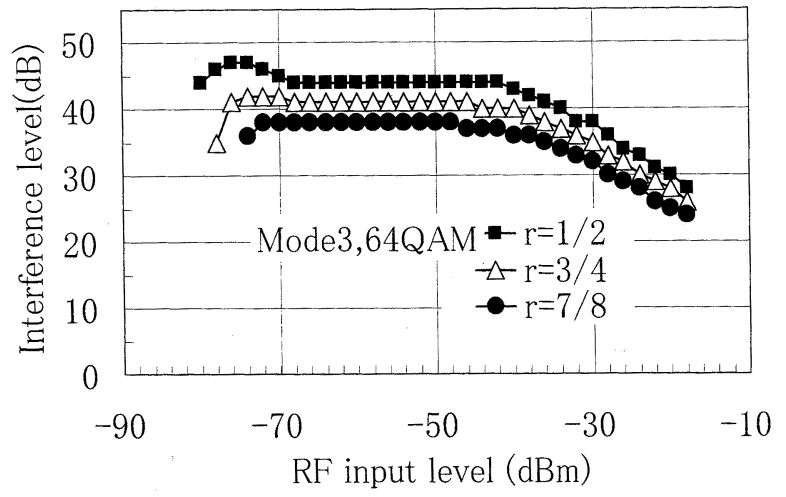

図 12 下側隣接チャネル干涉特性 Lower adjacent-channel interference (at $\mathrm{BER}=2 \mathrm{E}-4)$.

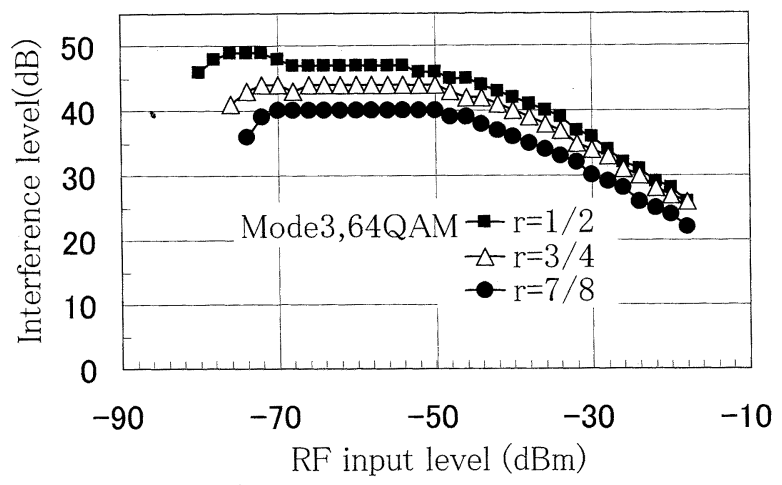

図 13 上側隣接チャネル干渉特性 Upper adjacent-channel interference (at $\mathrm{BER}=2 \mathrm{E}-4$ )

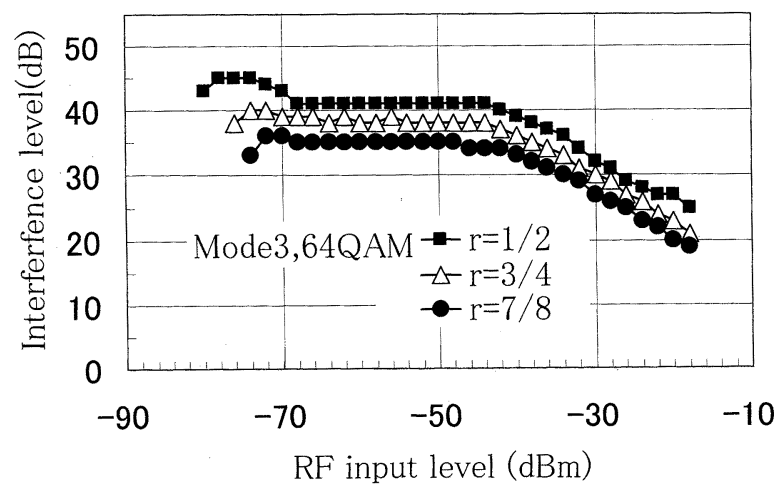

図 14 両側隣接チャネル干涉特性 Both side adjacent-channel interference $($ at $\mathrm{BER}=2 \mathrm{E}-4)$.
できる妨害レベルが減少している。これは希望波と妨 害波の合計が過大入力となり，チューナが非線形ひず みを生じたためである。

\section{(2) 上側隣接妨害}

下隣接妨害とほほ同様であるが，入力レベルが小さいと きの所要 $D / U$ はやや小さくてよい.これはアナログ 波スペクトルが周波数的に対象でないためである。た だし，入力レベルが $-45 \mathrm{dBm}$ 以上では差がない.

(3) 両側隣接妨害

上下隣接の妨害を同時に受けるが, IF 入力レベル -70 $\mathrm{dBm}$ から $-45 \mathrm{dBm}$ であれば符号化率 $r=7 / 8$ でも $D / U=-30 \mathrm{~dB}$ となった .

\section{4. モニタ機能と拡張機能について}

\section{1 外部 PC によるモニタ機能}

OFDM 受信機のモ二タ機能として表 5 に示す機能を用 意し，受信障害などの解析が容易にできるようにした。ま· た，外部にパソコン $(\mathrm{PC})$ を接続することにより，遅延プ ロファイルなどの簡易的なモニタリングも可能である.

図 15 に, マルチパス妨害環境下 $(D / U=3 \mathrm{~dB}$, 遅延量 5 $\left.\mu_{\mathrm{S}}\right)$ において受信した場合のモード表示, コンスタレーシ ヨン, 帯域内スペクトルおよび遅延プロファイルの表示例 を示す。

\section{2 オンエア記録機能 (拡張機能)}

OFDM 受信機にオンエア信号の記録機能を追加して機 能拡張した場合の構成図を図 16 に，解析機能を表 6 に示 す.

UHF の OFDM 信号を復調すると同時に, 復調前の IF 信号を記録できるように RAM 拉よびハードディスクド ライブ(HDD)を図 2 と同じ筐体に内蔵した。

記録した信号を読出して再度復調することにより，受信 障害状況などを繰り返し再現して解析することができる. 実際にフィールドで受信障害が発生した時に自動記録した 受信信号のスペクトルを図 17 に，等化後の復調出力 (横軸 が周波数)を図 18 に示す。等化後の復調出力において，矢 印で示した周波数成分に受信障害の主な原因となったスプ リアスが混入していることがわかる。

表 5 解析機能

Analysis function.

\begin{tabular}{|c|c|c|}
\hline \multirow{2}{*}{$\begin{array}{c}\text { 外 } \\
\text { 部 } \\
I / F\end{array}$} & BER I/F & $\begin{array}{l}\mathrm{BNC} \text { クロック, データ (ECL) } \\
\text { 外部 PC にて RS ON/OFF 可能 }\end{array}$ \\
\hline & $\begin{array}{l}\text { コンスタ } \\
\text { レーション }\end{array}$ & $\begin{array}{l}\mathrm{I}, \mathrm{Q} \text { 信号, クロック出力 } \\
1 \mathrm{Vp}-\mathrm{p} / 75 \Omega\end{array}$ \\
\hline \multicolumn{2}{|c|}{ 外部 $\mathrm{PC} \mathrm{I/F}$} & D-Sub 9 Pin (RS 232 C) \\
\hline \multicolumn{2}{|c|}{ 表示機能 } & $\begin{array}{l}\text { 簡易モニタリング } \\
\text { (1) コンスタレーション } \\
\text { (2) スペクトル } \\
\text { (3) 遅延プロファイル } \\
\text { (4) TMCC 情報など }\end{array}$ \\
\hline
\end{tabular}




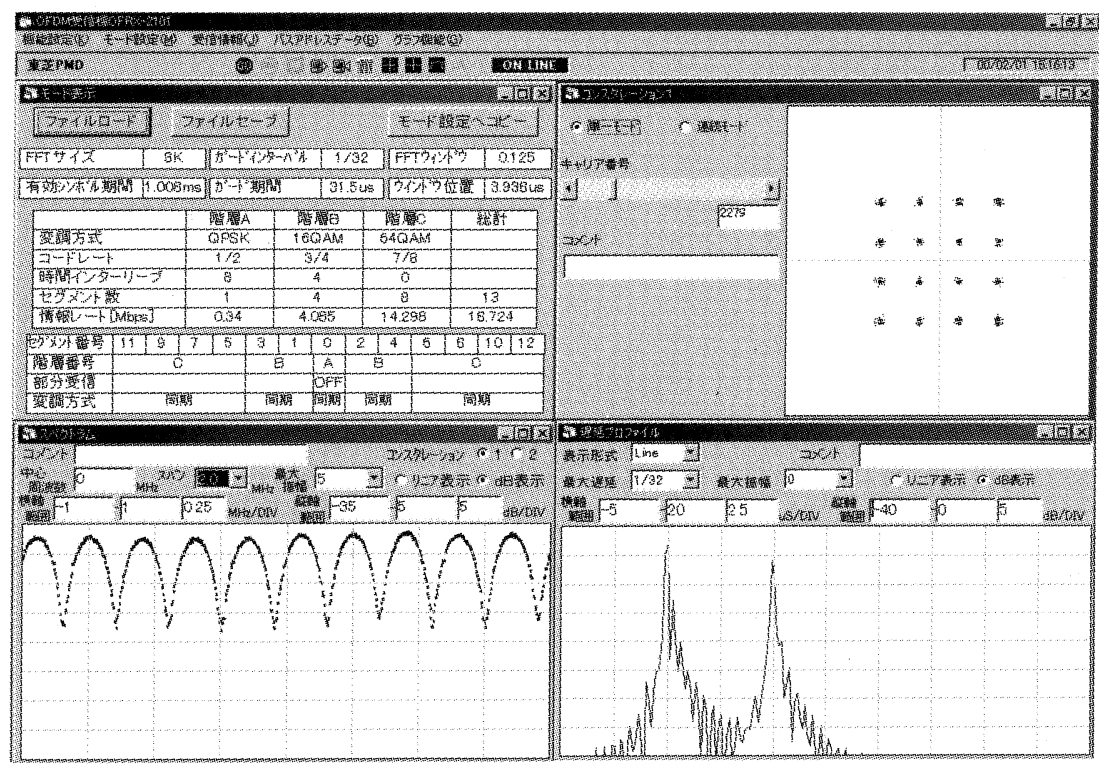

図 15 解析表示例 (マルチパス環境下)

The example of a display under multipath channel condition.

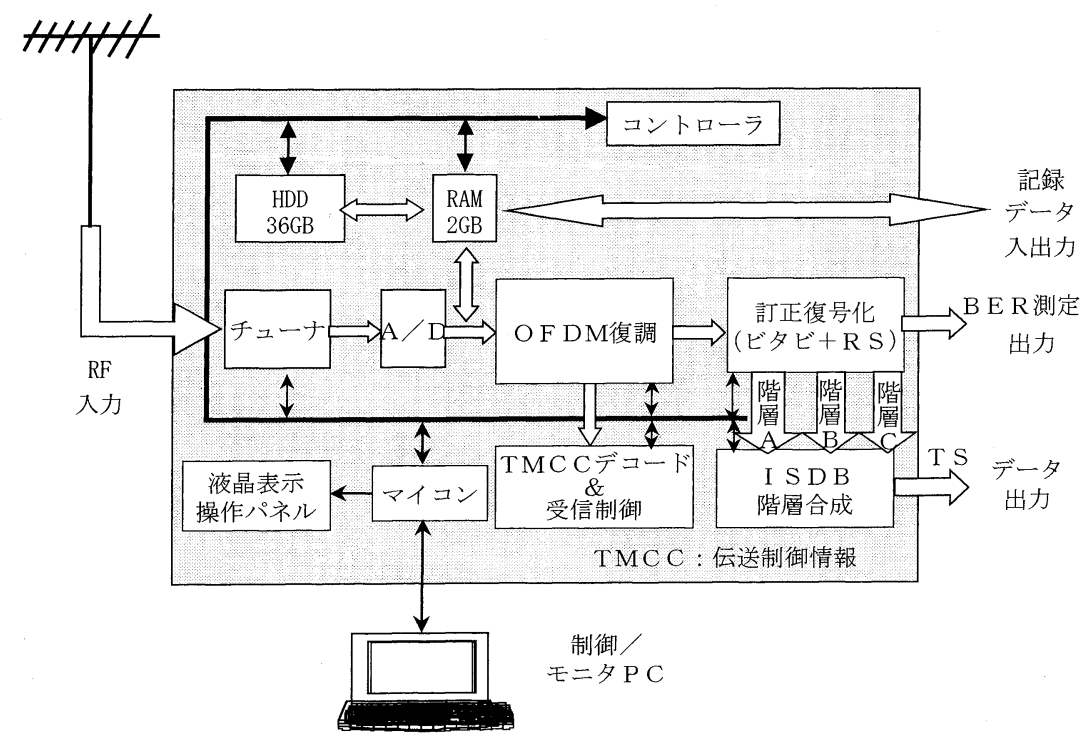

図 16 拡張機能

Block diagram of extended function.

表 6 オンエア解析機能

Specification of extended function.

\begin{tabular}{|c|c|c|}
\hline \multirow[t]{4}{*}{ 記録 } & 時間 & 最大 1 分間の変調信号を記録 \\
\hline & メモリー & $2 \mathrm{~GB}$ \\
\hline & デー夕 & $\begin{array}{l}\text { サンプリング } 16.3 \mathrm{MHz} \\
\text { (メモリーへは } 16 \text { bit で記録) }\end{array}$ \\
\hline & トリガ & $\begin{array}{l}\text { マニュアルまたはオート(伝送エラー発生前後 } 1 \text { 分間 } \\
\text { を採取） }\end{array}$ \\
\hline 再生 & 時間 & 最大 1 分間データのシングル/リピート再生 \\
\hline \multirow[t]{2}{*}{ 保存 } & HDD & $36 \mathrm{~GB}$ \\
\hline & ファイル数 & 最大 1 分間のデー夕を 16 個まで \\
\hline
\end{tabular}

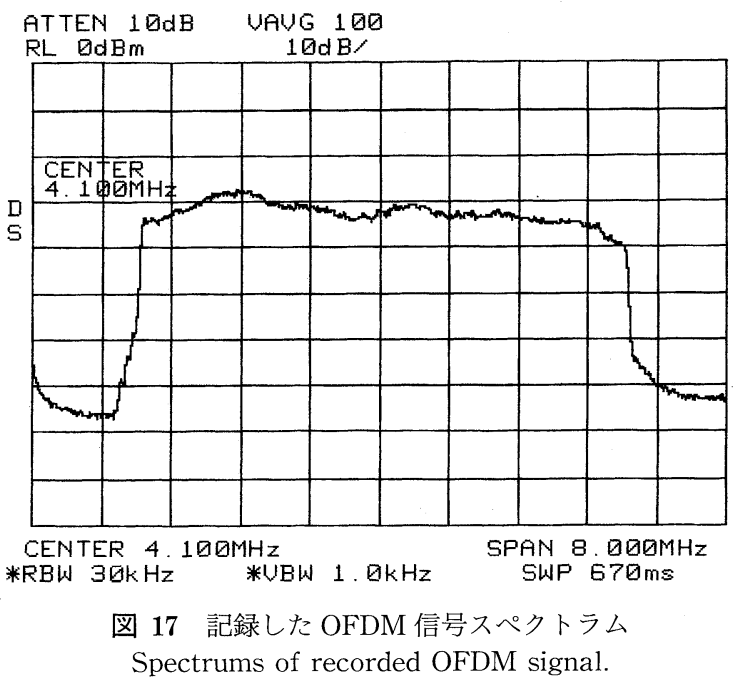

(159) 909 


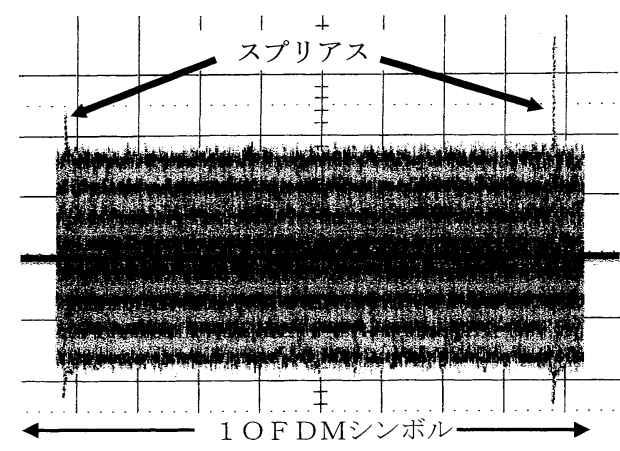

図 18 記録した OFDM 信号の FFT 出力 FFT output data of recorded OFDM signal.

\section{5. むすび}

開発した OFDM 受信機の概要と基本性能，および妨害 に対する受信性能の改善について報告した。マルチパス妨 害に対しては，キャリヤの平均振幅を求めて重みづけ訂正 を行うことで性能改善できることを確認し，同一チャネル 妨害に対しては各キャリヤのコンスタレーションの分散を 求めてキャリヤごとに消失詋り訂正を行うことで，受信性 能が改善できた。

また, OFDM 信号をリアルタイムで記録再生する機能 を拡張した。フィールドでの受信障害解析, 受信デー夕採 取装置として有用である。

\section{〔文献〕}

1）電気通信技術審議会デジタル放送システム委員会報告書, “地上デジタ ルテレビジョン放送方式の技術的条件”（May 1999）

2）中原俊二, 高田正幸, 土田健一，黒田徹: “マルチパス伝送路に打ける 64 QAM-OFDM 信号の軟判定復号法の検討”, 映情学技報, 22, 34, pp. 7-12 (June 1998)

3）原田啓介, 相沢雅己，佐藤誠，杉本雅彦：“地上伝送路を考慮した誤り制

御”, 映情学年次大 3-1, p. 31 (July 1998)

4）中原俊二，岡野正寛，居相直彦，木村智: “アナログテレビ干渉による地 上デジタル放送信号の干渉特性と特性改善”, 映情学技報, 23,34 , pp. 712 (May 1999)
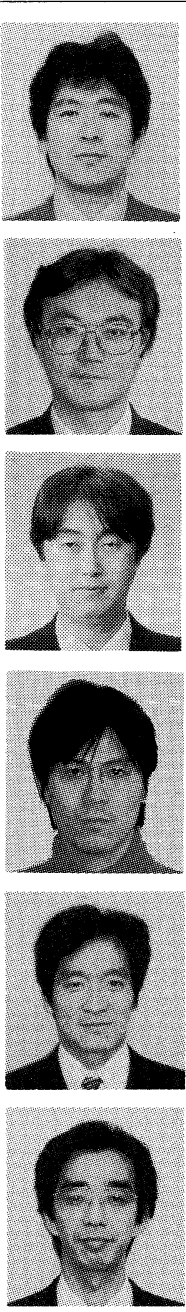

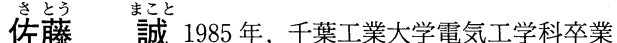
同年, 東芝 AVE(株) (現 東芝デジタルメディアエン ジニアリング(株)) 入社. ハイビジョン機器, 映像伝送 機器開発を担当. 現在, 地上ディジタル放送の研究開発 に従事. 正会員.

交籐 加品也 1984 年, 岩手大学工学部電気工学科卒 業. 同年，(株)東芝入社. マルチメディア対応高周波モ ジュール開発に従事．正会員。

関隆史 1992 年, 東北大学大学院工学研究科修 士課程修了. 同年, (株) 東芝入社. 1995 年 1999 年, (株) 次世代デジタルテレビジョン放送システム研究所兼 務. 地上ディジタル放送の研究開発に従事。

相沢 雅己 1990 年, 慶鷹義塾大学理工学部計測工 学科卒業。同年，(株)東芝入社. 1995 年〜1999 年, (株) 次世代デジタルテレビジョン放送システム研究所兼 務.ディジタル放送伝送路符号化の研究開発に従事. 正 会員.

多賀算 1989 年, 芝浦工業大学工学部電気工学 科卒業. 同年, 東芝 AVE(株) (現 東芝デジタルメデ イアエンジニアリング(株)）入社。ディジタル放送変復 調システムの研究開発に従事. 正会員.

坚加達也 1981 年, 北海道大学大学院工学研究科 修士課程修了。同年，(株) 東芝入社. 1995 年 1999 年, (株) 次世代デジタルテレビジョン放送システム研究所兼 務. ディジタル放送の研究開発に従事. 正会員。 